\title{
Prioritization of Russian Regions for Sustainable Investing Purposes Using Data Envelopment Analysis"
}

\author{
Anastasia ARKHIPOVA \\ Ernst \& Young Valuation and Advisory Services, Moscow \\ Nastyaa@inbox.ru
}

\begin{abstract}
In the article we propose to use recently developed method, namely the robust shared-input Data Envelopment Analysis (DEA), to estimate the attractiveness of regions in the view of Sustainable Investing (SI). We apply DEA method over all regions of Russian Federation to identify a preferred alternative, to rank the alternatives in a decreasing order of preference and to classify the alternatives into a small number of categories for SI purposes using social-economic data for the latest available period (2013) and mathematical programming tools (Linear programming in RStudio). We argue that too little attention has been paid to the way regional sustainability and its determinants should be empirically analyzed. This article aims at presenting a methodology that provides a convenient and scientifically sound way of evaluation and monitoring of efficiency of SI in Russian regions. In order to determine possible practical application of obtained results, in our article we highlighted the role of hybrid financing in the frame of sustainable development and analyzed current gaps in the Russian legislation. It is hoped that this article will be useful for practitioners who are engaged in research and applications of operations research and performance measurement, including those who work in the field of economics.
\end{abstract}

\begin{abstract}
Аннотация. В данной статье методология «Анализ среды функционирования» (АСФ) используется для определения приоритетных субъектов Российской Федерации в рамках проведения «ответственной» инвестиционной политики. АСФ проводится по всем субъектам Российской Федерации с целью категоризации альтернатив, определения наилучшей и ранжирования регионов для целей устойчивых инвестиций на основе социально-экономических данных за последний доступный период (2013 г.) с помощью инструментов математического программирования (линейного программирования в RStudio). Мы полагаем, что на текущий момент недостаточно внимания уделяется практическим аспектам анализа устойчивости регионов и решающих факторов их развития. В данной статье вашему вниманию предлагается удобная и научно-обусловленная методология оценки и мониторинга эффективности ответственного инвестирования в регионы России. Для определения возможного практического применения полученных результатов в статье подчеркивается роль гибридного финансирования в устойчивом развитии, а также проводится анализ необходимых изменений законодательной базы. Данная статья будет полезна для практиков, принимающих участие в работах по исследованию и внедрению исследований в операционную деятельность и оценке эффективности процессов (в том числе для тех, кто работает в области экономики).
\end{abstract}

Key words: Efficient Russian regions, long-term investing in Russia, DEA for sustainability, ranking regions, PPP, DEA.

\section{INTRODUCTION}

Regions are seen as having an increasingly important role in sustainable development (SD). First of all, this focus is justified by the important role of regions as intermediaries between the national and local levels and, secondly, by the growing consensus that SD is an essential criterion within future regional development.
Paul Erlich said: "We must acquire a life style which has as its goal maximum freedom and happiness for the individual, not a maximum Gross National Product." We agree that a financial indicator represented on the regional level in the form of Gross Regional Product (GRP) cannot discover potential for improvement within a region, as one input one output approach cannot give the whole picture of perfor-

\footnotetext{
*Анализ инвестиционной привлекательности российских регионов методом DEA.
} 
mance efficiency. That is why crucial feature of SD lies in adaptation of an integrated vision and other factors are necessary for a holistic assessment of performance.

It is difficult to combine the entire set of ratios into a single numeric judgment, so we find the solution in application of Data Envelopment Analysis (DEA) technique. The main advantage of this method can be easily understood if you paraphrase the name "data envelopment analysis" - the efficient frontier envelopes (encloses) all the data we have. Mathematically the efficient frontier is the convex hull of the data that shows best possible performance that each constituent entity of Russian Federation could reasonably be expected to achieve.

DEA's empirical orientation and absence of a priori assumptions have resulted in its use in a number of studies involving efficient frontier estimation in the nonprofit sector, in the regulated sector, and in the private sector. In our study all of these sectors are combined in the form of public-private partnership (PPP).

The main objective of our research is to show performance, metrics, and pitfalls of this increasingly popular technique using as example one real life performance measurement problem: prioritization of regions in accordance with their attractiveness for sustainable investing (SI) purposes.

\section{CONCEPT OF STRATEGIC SI APPROACH}

"SI" is one of many terms used to describe strategies that aim to maximize social good and financial returns. Others include "social”, "ethical”, "mission-based" or "impact" investing. Whether the goal is to promote improved environmental, social, or governance practices, or to protect the value of one's assets, SI is moving from niche status to a broader-based acceptance.

The evolution of SI stretches over centuries. Religious investors from Jewish, Christian, and Islamic faiths and many indigenous cultures have long married morals and money, giving careful consideration to the way economic actions affected others around them and shunning investments that violated their traditions' core beliefs. In the American colonies, Quakers and Methodists often refused to make investments that might have benefited the slave trade, for example, and the earliest formalized ethical investment policies avoided so-called "sin" stocks companies involved in alcohol, tobacco, or gambling. Indeed, the first fund to incorporate such sin-stock screening was the Pioneer Fund, opened in 1928 and screened since 1950 to meet the needs of Christian investors seeking to avoid involvement in such "vice" industries. The Fund continues to exclude tobacco, alcohol, and gambling industries from its portfolio to this day.

SI in its present-day form, however, arose in the aftermath of the social and cultural upheaval of the 1960 s, an outgrowth of the civil-rights, feminist, consumer, and environmentalist movements and protests against the Vietnam War, which raised public awareness about a host of social, environmental, and economic problems and corporate responsibility for them. Religious organizations and institutional investors remained very much at the forefront of these concerns about corporate social responsibility and, in the 1970s, US institutions developed support to the emergent sustainable investing industry: the Investor Responsibility Research Center (IRRC) and the Interfaith Center on Corporate Responsibility (ICCR). The US Council on Economic Priorities began rating companies on social and environmental performance in 1969, and shareholder advocates turned to the proxy-resolution process to raise issues of concern at annual company meetings.

But in our research SD is outlined for the macroeconomic level, so the starting point for any measurement of the regional sustainability should be "Our Common Future", also known as the Brundtland Report, published in 1987 by the UN WCED, which coined $\mathrm{SD}$ as an integrative concept aiming to balance environmental and economic issues in a mutually beneficial way. Regarding its thematic breadth, issues other than strictly environmental were incorporated. While initially economic and social issues were addressed only as far as they were perceived to be relevant for environmental concerns, they evolved into equally important dimensions of SD.

The central thesis of the Brundtland Report is that "SD is not a fixed state of harmony, but rather a process of change, in which the exploitation of resources, the direction of investments, the orientation of technological development, and institutional change are made consistent with future as well as present needs."

\section{THE ROLE OF HYBRID FINANCING STRATEGIES IN SD}

Back in "Our Common Future" Gro Harlem Brundtland expressed the idea that "SD must rest on political will as the process is not straightforward and contemplates painful choices", which seems reasonable, but as budgets tighten and the public purse is pulled in many directions, it does not seem feasible. Thus the most eligible way of investing for the purposes of SD is cooperation of governments and development banks with the private sector. Public infrastructure deficits are compelling governments to bring in private sector 


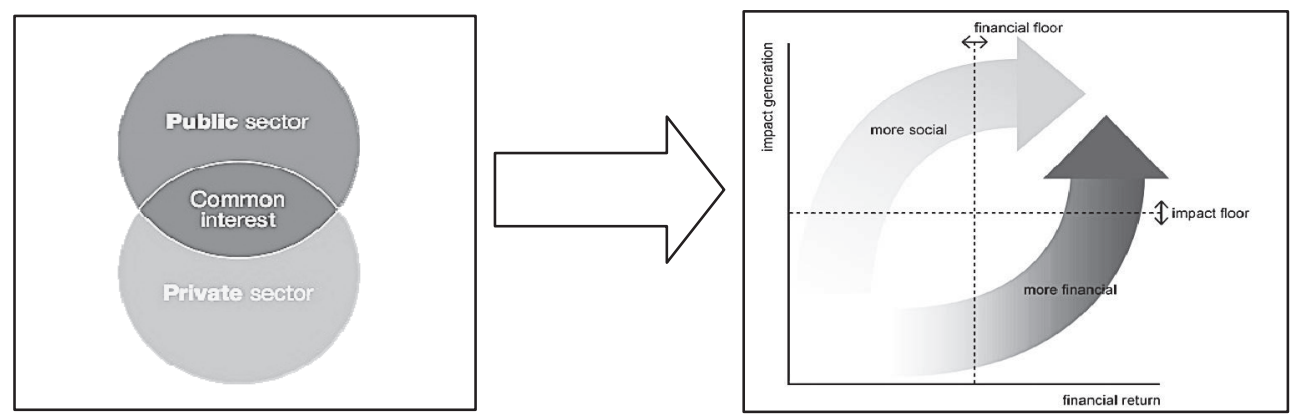

Figure 1. PPP: Combination of financial and social return.

capital and management efficiency through arrangements known as PPPs.

In today's economic environment, PPPs are defined as contractual agreements between a public agency or public-sector authority and a private-sector entity that allow greater private participation in the delivery of public services, or in developing an environment that improves the quality of life for the general public. PPPs can be used not only in the creation of physical assets and services, but also to meet wider environmental and social goals.

PPPs refer to arrangements where the private sector supplies infrastructure assets and services that traditionally have been provided by the government. They are mainly used to build and operate hospitals, schools, prisons, roads, bridges and tunnels, light rail networks, air traffic control systems, and water and sanitation plants.

This recently developed form of cooperation provides an agenda for action for purely financially motivated investors eager to mitigate risks and benefit from upside opportunities, as well as for governments seeking long-run economic development and civil society organizations aiming to achieve social and environmental progress (Figure 1).

There are advantages for both contract parties: for the government private financing can support increased infrastructure investment without immediately adding to government borrowing and debt, and can be a source of government revenue. At the same time better management in the private sector and its capacity to innovate can lead to increased efficiency; this in turn should translate into a combination of better quality and lower cost services. For the private sector PPPs present business opportunities in areas from which it was in many cases previously excluded.

In order to activate PPPs in the regions of our country the Ministry of Economic Development has carried out expertise assessments concerning law enforcement and concluded that in order to attract investment in infrastructure projects, certain amendments in federal budget, investment, land and tax legislation are needed.
To that end the Ministry of Economic Development has developed two laws "On public-private partnerships" and "On amendments to legislation in connection with the 'On public-private partnerships' bill”.

Introduction of the law regulations of PPPs at a federal level will allow to develop unified terminology, principles, tender procedures and even to create regulatory acts in the regions. The law sets out essential conditions and guarantees legal rights for PPP participants by maintaining the authority to control the activity of the private partner during project implementation regarding contractual commitments.

Moreover, the improvement of the law "On concessions" is taking place. In 2012 a number of amendments have been passed. New forms of concessions have been added, for example, the possibility to conclude the Life Cycle Contracts or so-called "DBFM (Design-Build-Finance-Maintain)" Model, when the private sector designs, builds and finances an asset and provides hard facility management or maintenance services under a long-term agreement.

Summing up all above-mentioned, we can say that for PPPs to be leveraged for environmental, social and economic sustainability, leadership and political will are the keys, both in terms of the overall policy framework for PPPs and from contracting parties at individual project level. This research, screening, and final ranking aim to provide a background, stimulate ideas and motivation to ease the process of making investment decisions and maximize the benefits of future long-term investments both for investor and the society.

\section{DEA vs CUMULATIVE EXPERIENCE IN ANALYSIS OF PROJECT ALTERNATIVES}

Any evaluation must have a starting point and purpose. Evaluation can be done in different phases of a project - ex-ante, in medias res, or ex-post (before, while or after a project is carried out). Regardless which phase of a project the same methods are applied, there are three basic forms or analysis: 


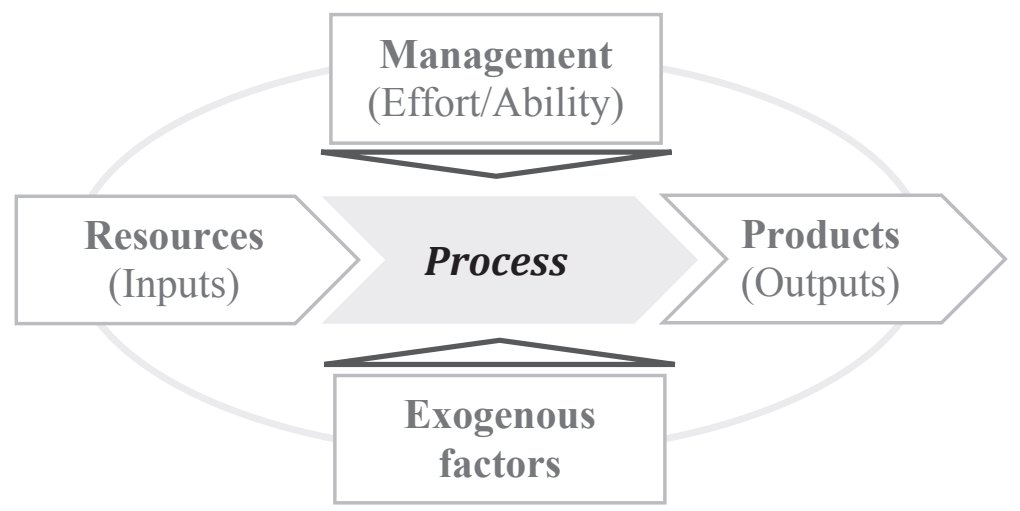

Figure 2. Visual explanation of DEA approach.

1. Cost-Benefit Analysis (CBA);

2. Cost-Effectiveness Analysis (CEA);

3. Multi-Criteria Analysis (MCA).

The CBA is an evaluation method that gives an overview of advantages and disadvantages of project alternatives or measures in terms of social welfare. These advantages and disadvantages are presented in the form of cost items and benefit items on a cost-benefit balance sheet. The items are expressed in terms of money ("monetized") as far as possible to enable the various project alternatives to be compared. CBA is a weighing-scale approach to making business decisions: all the pluses (the benefits) are put on one side of the balance and all the minuses (the costs) are put on the other. The main question in a CBA is "Do the benefits outweigh the costs?" The welfare effect is expressed in the balance of all costs and benefits. The costs and benefits of alternatives can also be compared to determine which alternative is preferable.

The aim of a CEA identifies the economically most efficient way to fulfill an objective. The analysis method can also be used to determine project alternative, given the maximum budget that will contribute most to the achievement of the objective (effect maximization). With a CEA, either the objective or the available amount of money is fixed.

A MCA, one of the most important branches of operations research, gives a decision-maker the opportunity to weigh a wide range of different effects against each other in the decision-making process. MCA aims to design mathematical and computational tools for selecting the best alternative among several choices, with respect to specific criteria, either by a single decision maker or by a group. MCA methods can be used to get large quantities of dissimilar information into a manageable form for decision-making. A MCA produces a "weighted sum" of the project's effects. For each project alternative, a number of criteria are used to give a weighing to each of the effects considered. The weightings determine how significant an effect is in the project alternative's overall score. The various alternatives are ranked in order of preference based on overall scores.

MCA includes DEA, which originates from production theory and implies that the performance of peer units, e.g. in this research we consider as regions, can be estimated by examination of the resources available to each unit and monitoring the "conversion" of these resources (inputs) into the desired returns (outputs) using mathematical programming techniques (Figure 2). The latter ones are frequently used as a planning aid to management to evaluate a collection of possible alternatives to select the best one.

\section{HOW TO MEASURE THE PERFORMANCE OF REGIONAL AUTHORITIES WITH DEA}

The first step of our research was to collect a very broad dataset of regional characteristics for the latest available period (2013). Our DEA study started with an exhaustive initial list of inputs and outputs: more than 70 variables were considered that were argued to be potentially related to differences in regional sustainability, but later it turned out that the more inputs and outputs are included in the analysis, the bigger is the percentage of regions that have an efficiency of 1 , as they become too specialized to be evaluated with respect to other DMUs. In other words it is possible for DMUs to concentrate on a few inputs and/or outputs and score highest efficiency ratings, leading to large number of DMUs with the highest efficiency coefficient. Therefore, one ought to include only the inputs and outputs that are definitely relevant to all DMUs. Including too many inputs and outputs into the analysis will tend to make many regions efficient and the method loses its discriminatory power or its ability to distinguish the high performers from the rest. To put it differently, we are unable to estimate complex technologies of high dimensionality using a lot of data points. 


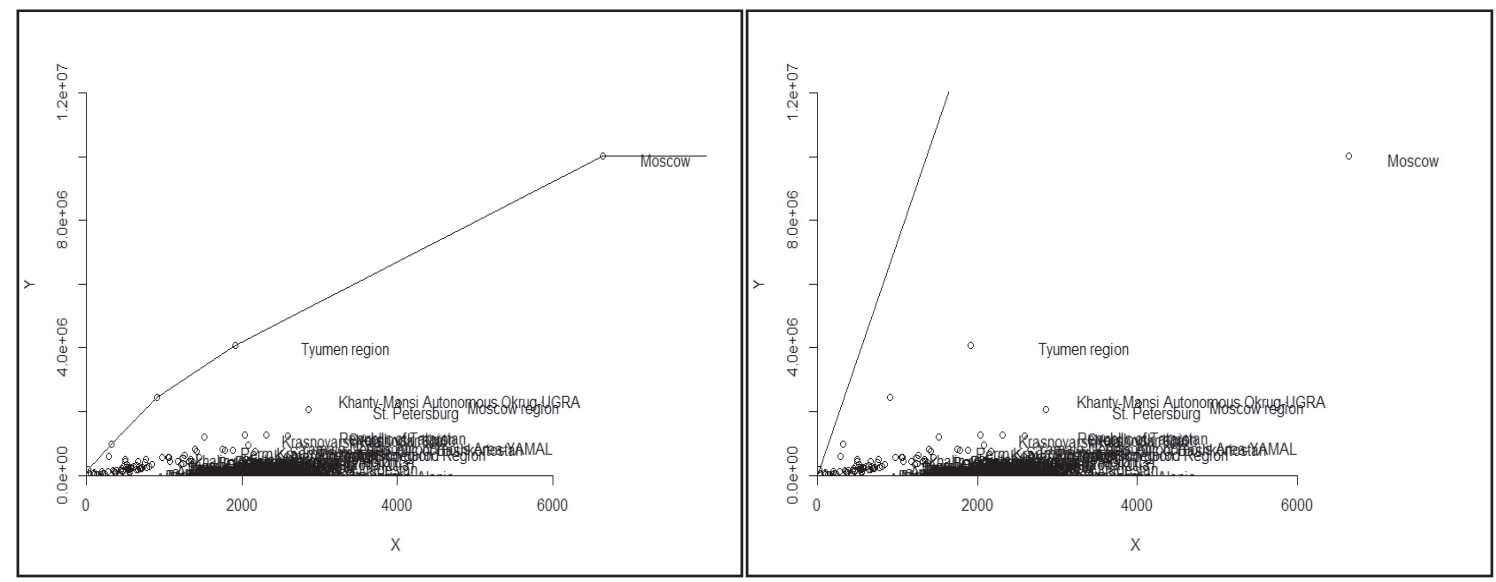

Chart 1. R-plot: VRS and CRS.

For these reasons, DEA researchers suggest using the rule of thumb for the relationship between the number of DMUs and the number of inputs and outputs, whereas the traditional rule says that the number of regions (or any other DMUs taken) must exceed 3 times the number of inputs plus the number of outputs, and the number of regions must exceed the product of the number of inputs and the number of outputs. These requirements are definitely at the low end and one can propose another rule. In order to make our esteems more precise we selected 30 most important variables and distributed them among 5 subject DEA models so that each model contained no more than 3 inputs and 3 outputs.

The main difficulty in any application of DEA lays in the selection of inputs and outputs. The criteria of selection of these inputs and outputs are quite subjective as there is no specific rule in determining the procedure for that. However, some guidelines may be suggested: one should pick up the most important quantitative (e.g., statistical) information and therefore to reduce the total number to a reasonable level.

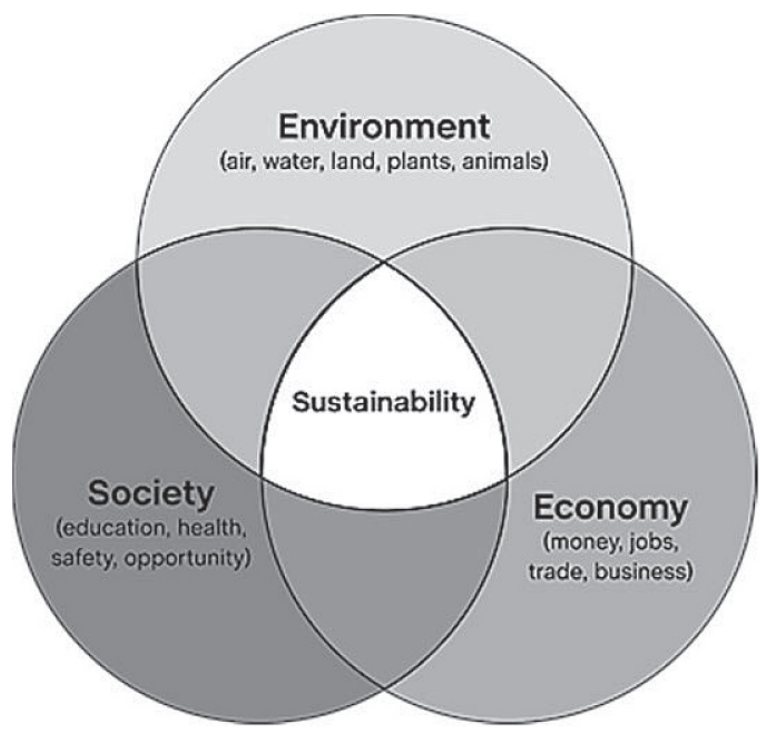

Figure 3. Three pillars of SD.
We were willing to prioritize regions not only in terms of their profitability (as usually is done by firms), so we considered inputs and outputs more generally than just costs and profits. We defined inputs as resources utilized by the DMUs or conditions affecting the performance of DMUs, while outputs were considered as benefits generated as a result of the operation of the DMUs.

In any study it is important to focus on specifying inputs and outputs correctly. In some cases it was difficult to classify a particular factor as input or output, as the factor could be interpreted in both ways. One of possible solutions implies the review on whether DMU, which performance is recorded as high in terms of that factor is considered more efficient or not. If yes, we classify the factor as an output. Otherwise, it is considered to be an input.

Traditional DEA models or so-called "base-oriented models" implicitly assume that factors (inputs and outputs) are discretionary, which means that they are controllable and can be set up by the decision-maker in order to achieve an optimal mix for production purposes. However, in many realistic situations, variables are exogenous and non-discretionary and depending on which variable is fixed we decide whether to use input- or output-oriented model. Input-oriented models are models where DMUs are deemed to produce a given amount of outputs with the smallest possible amount of inputs (inputs are controllable) and are frequently used in costs cutting. In the case of Russian regions, most inputs are non-discretionary. With output-oriented DEA, the LP is configured to determine entity's potential output given its inputs if it operated efficiently as entities along the best practice frontier. Output-oriented models are "...very much in the spirit of neo-classical production functions defined as the maximum achievable output given input quantities". For instance, the regional governments cannot directly and naturally change the amount of 


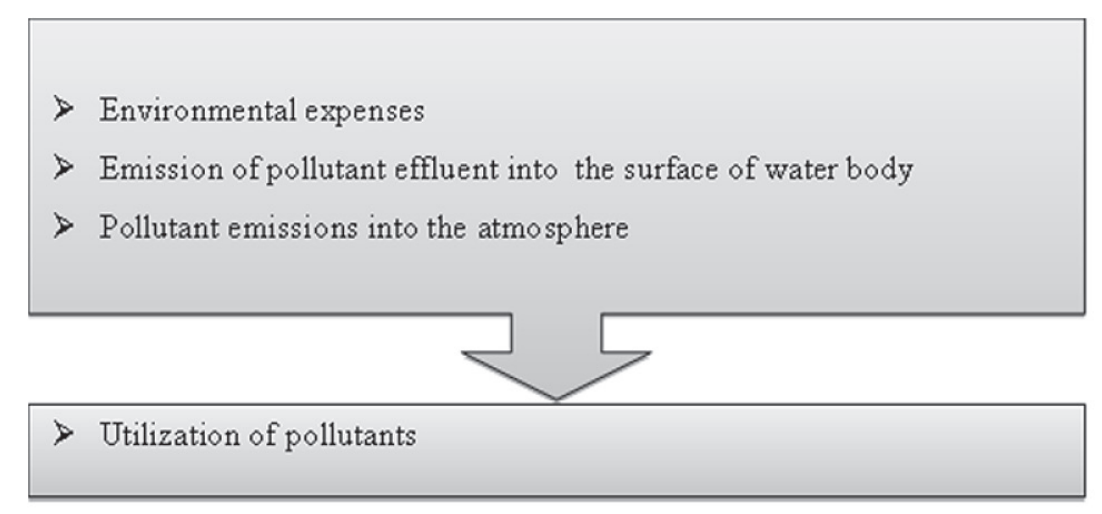

Figure 4. System of inputs and outputs that assess environmental issues.

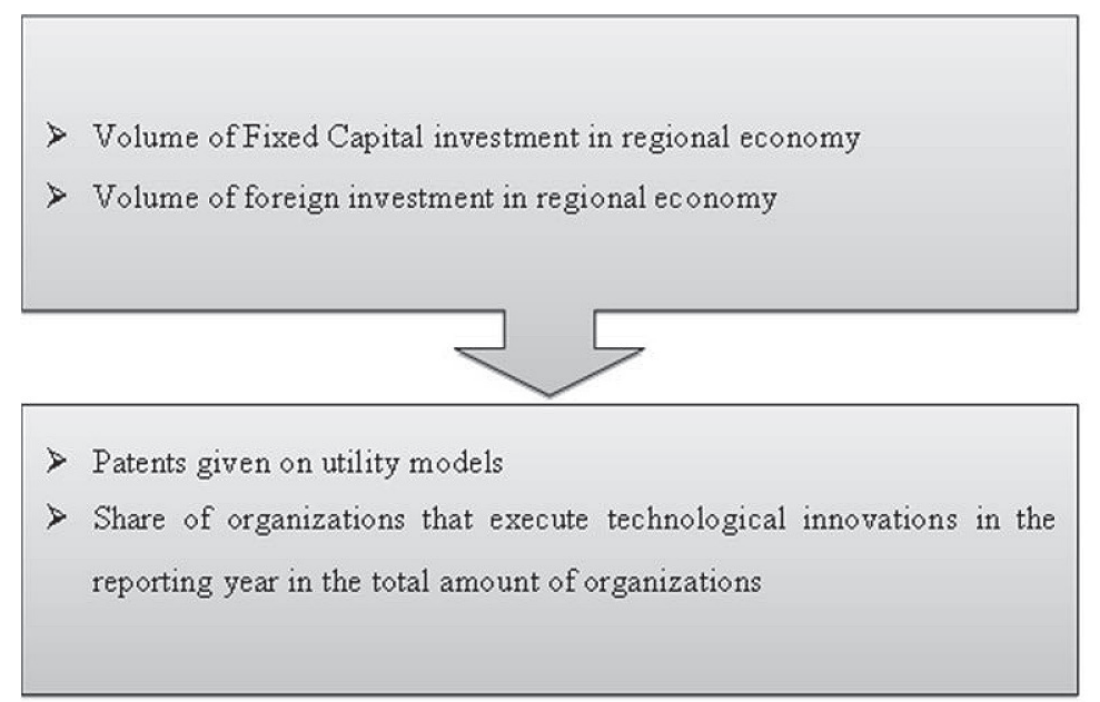

Figure 5. System of inputs and outputs that evaluate the development of infrastructure.

labor force, so we used the methodology that enabled to include non-discretionary variables in DEA. This is mainly done by maximizing/ minimizing only discretionary outputs/ inputs in the Linear Program (LP) model.

DEA can also integrate categorical variables (noncontinuous variables) in the LP model such as discrete ordinal variables (dummy variables). Other authors have analyzed the issue using categorical variables by proposing alternate formulation of the LP model. Several authors have proposed different formulations that account for ordinal variables. Consequently, DEA embodies all different types of variables, whether they are discretionary or non-discretionary, categorical (ordinal) or continuous.

Throughout this paper, we use R Project to perform our calculations and applications. $\mathrm{R}$ is a powerful language and environment for statistical computing and graphics. It is a public domain (a so-called "GNU" project), which is similar to the commercial $S$ language and environment, which was developed at Bell Laboratories (formerly AT\&T, now Lucent Technologies) by John Chambers and colleagues. It is quite similar to other programming packages such as MatLab but more user-friendly than programming languages such as $\mathrm{C}++$ or Fortran. In our research we used $\mathrm{R}$ in combination with the RStudio interface, where we downloaded package entitled "Benchmarking" in order to have an organized layout and several extra options.

One more common feature of DEA is that the envelopment surface differs depending on the scale assumptions that underpin the model. Two scale assumptions are generally employed: constant returns to scale (CRS), and variable returns to scale (VRS) (Chart 1).

The latter encompasses both increasing and decreasing returns to scale. CRS reflects the fact that output will change by the same proportion as inputs are changed (e.g. a doubling of all inputs will double output); VRS reflects the fact that production technology may exhibit increasing, constant and decreasing returns to scale. The CRS version is more restrictive than the VRS and as you will see further yields to a fewer number of efficient units and also lower efficiency scores among all DMUs. Input- and outputbased capacity measures are only equivalent under the assumption of CRS. 


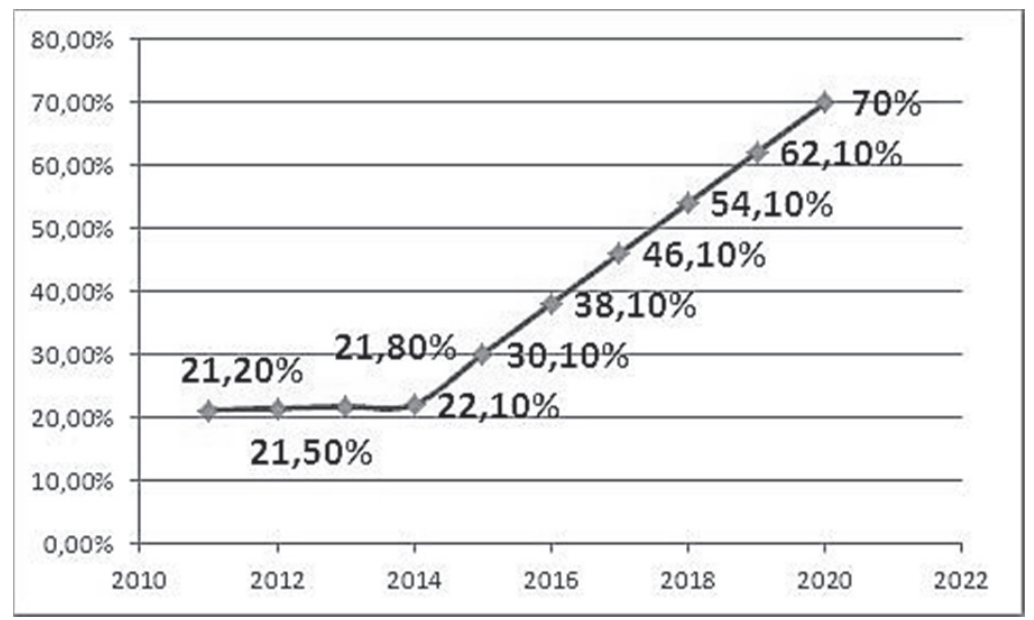

Chart 2. Forecast for the share of SME in GNP.

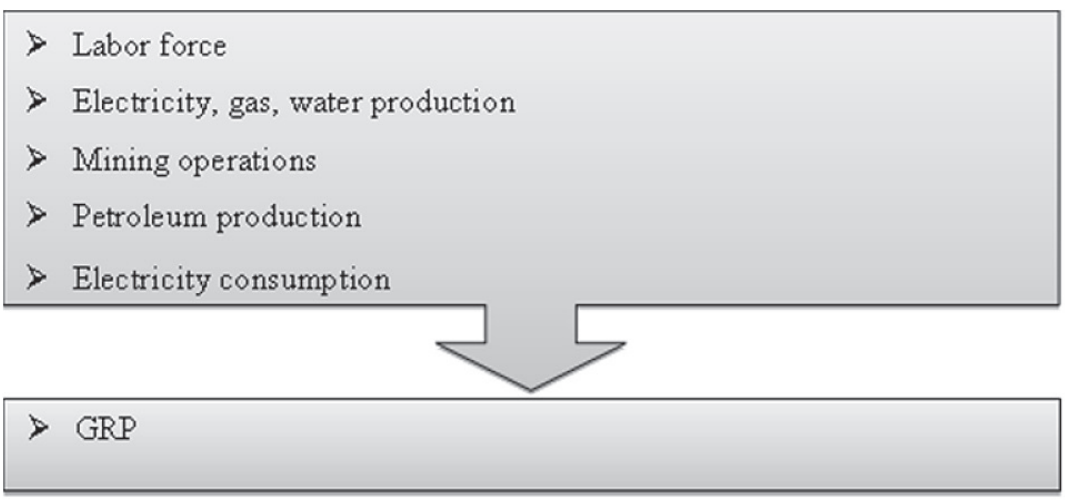

Figure 6. System of inputs and outputs to measure profitability.

In order to estimate the efficiency of regions we divided all the appropriate parameters into five categories (indices) which together form a complex picture of the region in terms of sustainability. First and foremost, sustainability can be achieved only in case all of three SD pillars are taken into consideration (Figure 3).

For all of them we set threshold values of efficiency that the regions must obtain in order to take part in the sustainability ranking. We conducted screening and if a region did not have the required efficiency coefficient in one of those indices, it meant that the strategy of development that was determined by regional authorities did not coincide with the strategy of sustainable growth so there was no use to invest in this region from that point of view.

The minimal values for each cluster were determined in accordance with the overall efficiency scores that DMUs obtained. In other words, to participate in the ranking DMU must obtain at least average efficiency for each of the SD pillars:

- Environment Index (Figure 4) with the minimal requirements to obtain 0,01 points out of 1 for environmental aspects: unfortunately, the average efficiency of green management are that low and to add to the trouble very often inverse correlation is observed between financial and environmental variables.

- Infrastructure Index (Figure 5) with a minimal requirement to obtain 0,45 points out of 1 as no projects can be realized in the location that are cut off from the outside world or controlled by local criminal authorities.

- Financial Index (Figure 6) with a minimal requirement to obtain 0,25 points out of 1 as sustainable investments as SI are neither synonymous with philanthropy nor an alternative; the profit is still the key issue of it.

Concept of Long-Term Socio-Economic Development of Russian Federation until 2020 determines key strategic aims that are diversification of regions through the increase of share of small and medium enterprises (SMEs).

By 2020 the share of SME in GNP will grow by 60 $70 \%$ which means that in the following six years it is to be tripled in comparison with the current situation (Chart 2). 
Table 1. Screening test results.

\begin{tabular}{|c|c|c|c|}
\hline \multirow[t]{2}{*}{ Constituent Entity of Russian Federation } & \multicolumn{3}{|c|}{ Efficiency Coefficient (scale from 0 to 1 ) } \\
\hline & Financial & Environmental & Infrastructural \\
\hline Altai Krai & 1,000 & 0,006 & 0,365 \\
\hline Altai Republic & 1,000 & 1,000 & 0,488 \\
\hline Amur region & 0,146 & 0,004 & 0,330 \\
\hline Arkhangelsk region & 0,163 & 0,004 & 0,441 \\
\hline Astrakhan region & 0,177 & 0,013 & 0,270 \\
\hline Belgorod region & 0,180 & 0,009 & 0,442 \\
\hline Bryansk region & 0,395 & 0,078 & 0,610 \\
\hline Chechen Republic & 0,244 & 1,000 & 0,362 \\
\hline Chelyabinsk region & 0,179 & 0,002 & 0,506 \\
\hline Chukotka Autonomous Area & 0,790 & 0,000 & 0,908 \\
\hline Chuvash Republic & 1,000 & 0,011 & 0,501 \\
\hline Irkutsk region & 0,215 & 0,001 & 0,328 \\
\hline Ivanovo region & 0,543 & 0,054 & 0,397 \\
\hline Jewish autonomous region & 0,384 & 0,198 & 0,543 \\
\hline Kabardino-Balkar Republic & 0,646 & 0,105 & 0,899 \\
\hline Kaliningrad region & 0,260 & 0,032 & 0,466 \\
\hline Kaluga region & 0,254 & 0,029 & 0,569 \\
\hline Kamchatka Krai & 0,242 & 0,092 & 0,594 \\
\hline Karachay-Cherkess Republic & 0,626 & 0,116 & 0,335 \\
\hline Kemerovo region & 0,094 & 0,003 & 0,347 \\
\hline Khabarovsk Krai & 0,137 & 0,001 & 0,517 \\
\hline Khanty-Mansi Autonomous Okrug - UGRA & 0,016 & 0,000 & 0,825 \\
\hline Kirov region & 0,513 & 0,004 & 0,430 \\
\hline Komi Republic & 0,070 & 0,004 & 0,499 \\
\hline Kostroma region & 0,814 & 0,063 & 0,562 \\
\hline Krasnodar Krai & 1,000 & 0,009 & 0,628 \\
\hline Krasnoyarsk Krai & 0,161 & 0,002 & 0,501 \\
\hline Kurgan region & 0,667 & 0,014 & 0,410 \\
\hline Kursk region & 1,000 & 0,025 & 0,276 \\
\hline Leningrad region & 0,071 & 0,012 & 0,728 \\
\hline Lipetsk region & 0,181 & 0,001 & 0,614 \\
\hline Magadan region & 0,982 & 0,002 & 0,490 \\
\hline Moscow & 1,000 & 0,005 & 1,000 \\
\hline Moscow region & 1,000 & 0,003 & 0,763 \\
\hline Murmansk region & 0,441 & 0,011 & 0,366 \\
\hline Nenets Autonomous Area & 0,234 & 0,024 & 1,000 \\
\hline Nizhny Novgorod region & 0,129 & 0,007 & 0,679 \\
\hline Novgorod region & 0,496 & 0,015 & 0,593 \\
\hline Novosibirsk region & 0,166 & 0,006 & 0,482 \\
\hline Omsk region & 0,245 & 0,002 & 0,561 \\
\hline Orenburg region & 0,226 & 0,009 & 0,322 \\
\hline Oryol region & 0,470 & 0,068 & 0,255 \\
\hline
\end{tabular}




\begin{tabular}{|c|c|c|c|}
\hline \multirow[t]{2}{*}{ Constituent Entity of Russian Federation } & \multicolumn{3}{|c|}{ Efficiency Coefficient (scale from 0 to 1 ) } \\
\hline & Financial & Environmental & Infrastructural \\
\hline Penza region & 0,233 & 0,050 & 0,502 \\
\hline Perm Krai & 0,183 & 0,007 & 0,376 \\
\hline Primorsky Krai & 0,207 & 0,001 & 0,623 \\
\hline Pskov region & 1,000 & 0,111 & 0,544 \\
\hline Republic of Adygea & 0,572 & 0,435 & 0,428 \\
\hline Republic of Bashkortostan & 1,000 & 0,004 & 0,389 \\
\hline Republic of Buryatia & 0,426 & 0,010 & 0,354 \\
\hline Republic of Crimea & - & - & - \\
\hline Republic of Dagestan & 0,394 & 0,001 & 0,885 \\
\hline Republic of Ingushetia & 0,935 & 1,000 & 0,438 \\
\hline Republic of Kalmykia & 1,000 & 0,319 & 0,521 \\
\hline Republic of Karelia & 0,661 & 0,022 & 0,279 \\
\hline Republic of Khakassia & 0,333 & 0,012 & 0,284 \\
\hline Republic of Mari El & 0,380 & 0,041 & 0,449 \\
\hline Republic of Mordovia & 0,219 & 0,064 & 0,574 \\
\hline Republic of North Ossetia-Alania & 0,378 & 0,105 & 0,444 \\
\hline Republic of Sakha (Yakutia) & 0,098 & 0,001 & 0,576 \\
\hline Republic of Tatarstan & 0,243 & 0,001 & 0,398 \\
\hline Republic of Tyva & 1,000 & 0,121 & 0,378 \\
\hline Rostov region & 0,170 & 0,002 & 0,464 \\
\hline Ryazan region & 0,284 & 0,023 & 0,497 \\
\hline Sakhalin region & 0,052 & 0,001 & 1,000 \\
\hline Samara region & 0,123 & 0,005 & 0,341 \\
\hline Saratov region & 0,218 & 0,018 & 0,393 \\
\hline Sevastopol & - & - & - \\
\hline Smolensk region & 0,344 & 0,057 & 0,456 \\
\hline St. Petersburg & 1,000 & 0,002 & 1,000 \\
\hline Stavropol Krai & 0,444 & 0,015 & 0,415 \\
\hline Sverdlovsk region & 0,065 & 0,001 & 0,568 \\
\hline Tambov region & 0,618 & 0,034 & 1,000 \\
\hline Tomsk region & 0,151 & 0,000 & 0,402 \\
\hline Tula region & 0,152 & 0,008 & 0,457 \\
\hline Tver region & 0,349 & 0,020 & 0,483 \\
\hline Tyumen region & 0,019 & 0,002 & 1,000 \\
\hline Udmurt Republic & 0,349 & 0,013 & 0,260 \\
\hline Ulyanovsk region & 0,264 & 0,034 & 0,402 \\
\hline Vladimir region & 0,316 & 0,032 & 0,452 \\
\hline Volgograd region & 0,250 & 0,006 & 0,391 \\
\hline Vologda region & 0,088 & 0,008 & 0,995 \\
\hline Voronezh region & 0,134 & 0,004 & 0,517 \\
\hline Yamalo-Nenets Autonomous Area - YAMAL & 0,018 & 0,001 & 1,000 \\
\hline Yaroslavl region & 0,210 & 0,013 & 0,574 \\
\hline Zabaykalsky Krai & 0,881 & 1,000 & 0,293 \\
\hline
\end{tabular}




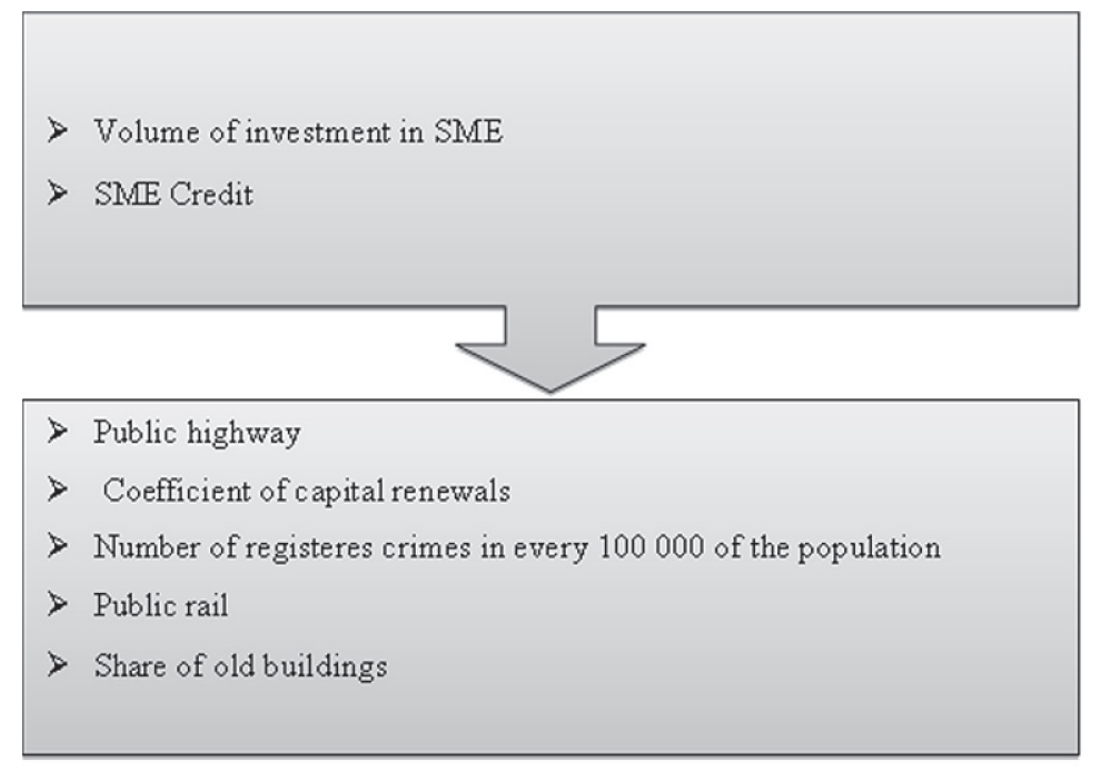

Figure 7. System of inputs and outputs that characterize entrepreneurial activity.

Being a roadmap for reforming Russia's social and economic spheres the Strategy 2020 should be the guideline for our Sustainable Development Investment Ranking, that is why we created SME index (Figure 7).

\section{INNOVATIVE DEVELOPMENT OF RUSSIA}

Russian authorities presented an exhaustive list of targeted key indicators within the context of Strategy for Innovative Development of the Russian Federation

Table 2. Innovative indicators tracking and targeting table.

\begin{tabular}{|c|c|c|c|}
\hline Key Indicators targeted & & Years & \\
\hline Performance & 2010 & 2016 & 2020 \\
\hline Education coverage in 5-14 y.o. group, \% & 94 & 98 & 100 \\
\hline Average teacher salary in\% to country's average wage & 65 & 80 & 100 \\
\hline Share of involved in lifetime learning process in $25-64$ y.o. group, $\%$ & 25 & 40 & 55 \\
\hline Number of patent applications per 10000 inhabitants & 2 & 3 & 4 \\
\hline Number of innovative industrial technologies created & 854 & 1500 & 2500 \\
\hline Innovation expenses share in GDP, \% & 1,4 & 2 & 2,5 \\
\hline $\begin{array}{l}\text { Share of cutting edge hi-tech equipment not more than } 8 \text { y.o. in overall amount of R\&D } \\
\text { equipment, \% }\end{array}$ & 45 & 65 & 85 \\
\hline Share of innovative goods in services in overall goods exported, \% & 7 & 12 & 15 \\
\hline Amount of nanotechnology-related goods and services, bn euro & 3 & 8,7 & 15 \\
\hline Share of companies employing technology innovations, \% & 8 & 15 & 25 \\
\hline $\begin{array}{l}\text { Amount of innovative SMEs, formed as spin-offs from universities and public research } \\
\text { organizations }\end{array}$ & 600 & 2000 & 4000 \\
\hline Number of working in R\&D per 10000 employed & 111 & & \\
\hline Average age of a researcher & 49 & 45 & 40 \\
\hline Share of governmental expenses in R\&D, \% & 65 & 50 & 35 \\
\hline $\begin{array}{l}\text { Russia's share in overall world amount of scientific publications, \% (acc. to Web of } \\
\text { Science) }\end{array}$ & 2,5 & 4 & 5 \\
\hline Place of Russia in information society development world ratings & & & 18 \\
\hline Share of organizations and companies with broadband internet access, \% & 48 & 85 & 95 \\
\hline
\end{tabular}




\begin{tabular}{|l|c|c|c|}
\hline \multicolumn{1}{|c|}{ Key Indicators targeted } & \multicolumn{2}{c|}{ Years } \\
\hline Share of companies and organizations with own websites, \% & 29 & 75 & 80 \\
\hline Share of households with internet access, \% & 26 & 75 & 90 \\
\hline Share of population utilizing internet to access governmental services, \% & 10 & 50 & 60 \\
\hline Financials, \% of GDP & 2010 & 2012 & 2020 \\
\hline Internal expenditures for R\&D & 1,3 & 1,5 & 2,4 \\
\hline Governmental expenditures for non-military R\&D & 0,88 & 0,9 & 1,1 \\
\hline Internal expenditures for education & 4,8 & 5,6 & 7,0 \\
\hline State expenditures for education & 4,0 & 6,0 \\
\hline Financials, bn euro & 2010 & 2012 & 2020 \\
\hline Governmental university funding & 0,4 & 0,4 & 0,6 \\
\hline Funding to attract international level scientists & 0,08 & 0,1 & 0,25 \\
\hline State funding to applied research and IPR commercialization & 0,7 & 1,8 & 3,6 \\
\hline State funding to basic research & 0,5 & 2,9 & 3,9 \\
\hline State funding to innovation infrastructure development (incl. Skolkovo) & 0,5 & 0,6 & 1,5 \\
\hline
\end{tabular}

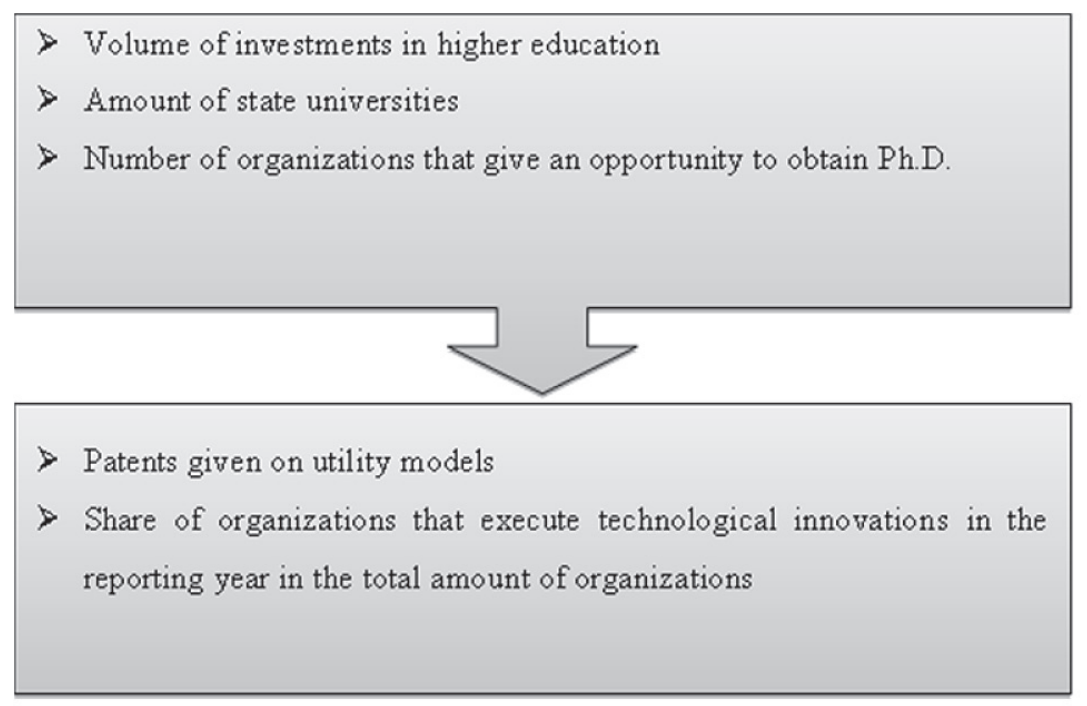

Figure 8. System of inputs and outputs that compute level of innovations.

2020, which provides long-term development milestones for the participants of the innovation process, gives guidelines on the investment policy within the basic and applied sciences and commercialization sectors (Table 2).

To follow the Innovative Strategy 2020 we designed model of innovative efficiency as well (Figure 8).

As a result we selected top 10 regions for each of two rankings that are created in accordance with country's strategic priorities (Figure 9), in which we recommend to invest for SD purposes: number of DMUs has resulted as efficient in DEA-CRS model. The initial data was taken for the year 2013, but for monitoring purposes it can be updated each year as the model is universal and does not require any script changes to be done, which is very convenient.

\section{DISCUSSION AND CONCLUSIONS}

In accordance with the conducted analysis Altai Republic received the highest efficiency score out of all regions for innovative activities, and this result coincides with the conclusions to which we arrive if we study publicly available information about this region: it is a member of innovation regions association, and some innovative clusters are already located there.

Jewish Autonomous Region shows the highest entrepreneurial efficiency but, despite that fact, according to the latest news the value of investments into the SME of the region has decreased significantly. If investors knew about DEA ranking for sustainable investing purposes, they could use that opportunity and get maximum return through proper investment allocation. 


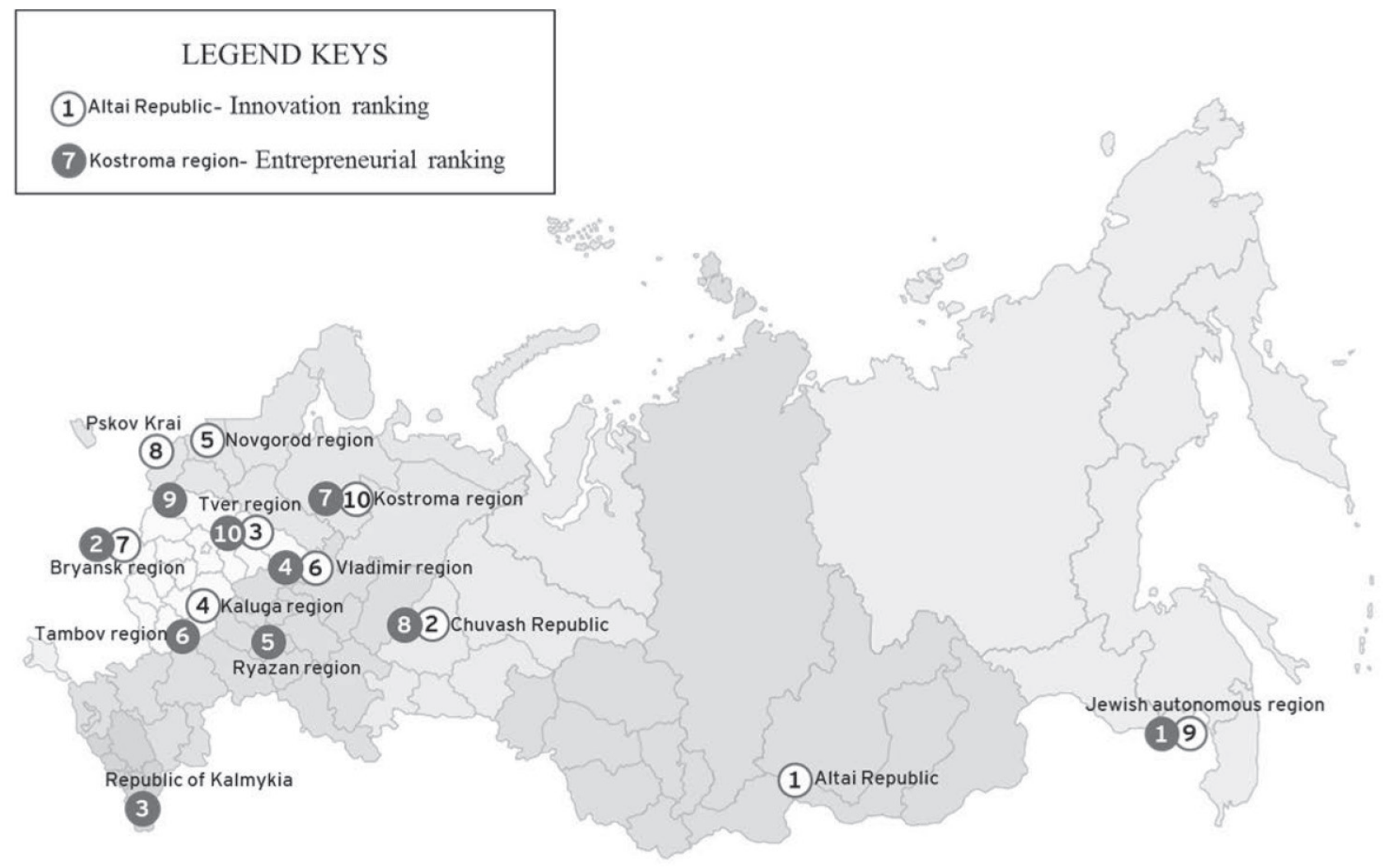

Figure 9. Top10 regions in terms of sustainability.

\section{REFERENCES}

Babker R.D. and Morey R.C., 1986. Efficiency analysis for exogenously fixed inputs and outputs, Operations Research, 34 (4), 513-521.

Behn R.D., 2003. Why Measure Performance? Different Purposes Require Different Measures, Harvard University, Public Administration Review, Vol. 63, No. 5.

Bogetoft P. and Otto L., Benchmarking with DEA, SFA, and R, 2011, Springer Science, New York.

Charnes A., Cooper W.W. and Rhodes E., 1978. Measuring the efficiency of decision making units, European Journal of Operational Research, 2, 429-444.

Clements B., Bhattacharya R. and Nguyen T.Q., 2003. External debt, public investment, and growth in low-income countries, IMF Working paper 03/249, Washington, DC.

Färe R., Grosskopf S. and Lowell C.A. K., 1994. "Production Frontiers”, Cambridge University Press, 95.

Figueira J., Greco S. and Ehrgott M., 2005. Multiple Criteria Decision Analysis: State of the Art Surveys, vol. 78, Springer Science, New York.

Thomas R., 2014. Datendesign mit R. 100, Visualisierungsbeispiele, Open Source Press, München.
Werbach A., 2009. When Sustainability Means More Than Green, McKinsey Quaterly, Issue 4, 74-79.

World Commission on Environment and Development, 1987. Our Common Future. Oxford University Press.

The Civil Code of the Russian Federation (Part I) N 51-FZ dated 30.11.1994.

The Civil Code of the Russian Federation (Part II) N 14-FZ dated 26.01.1996.

The Budget Code of the Russian Federation N 145-FZ dated 31.07.1998, Article 179.

Federal Law N 115-FZ dated 21.07.2005 “On Concession Agreements".

Federal Law N 94-FZ dated 21.07.2005 "On Placement of State (Municipal) Orders for Delivery of Goods, Execution of Works and Rendering of Services for State and Municipal Needs”.

Federal Law N 60-FZ dated 13.12.1994 "On Delivery of Goods for Federal State Needs".

Concept of long-term strategy of socio-economic development of Russian Federation until 2020 dated 17.11.2008.

The Ministry of Economic Development of the Russian Federation, 2011. Strategy for Innovative Development of the Russian Federation 2020, URL: http://government.ru/gov/rbillesults/ $17449 /$. 